\title{
The Effect of Foreign Remittances on the Economic Growth of Pakistan Economy
}

\author{
Salma Zahir \\ Department of Economics; Lecturer of Economics at Women's University Swabi \\ Dr Kausar Hayat \\ Department of Management Science; Assistant Professor Government College of Management Science Wana \\ South Waziristan Tribal district
}

\begin{abstract}
The present study empirically inspected with time-series data the effect of external remittances on Pakistan's economic growth from 1974-2019. For the data analysis, the unit root test for stationary and other techniques like the ARDL bound test for long-term co-integration and ECM for short-term is used. Research evidence revealed that foreign remittances, consumption, domestic savings, and exports seem to be positive and statistically significant with economic growth in the long run. While imports are statistically significant, but there is an inverse relation to Pakistan's economic growth. Nevertheless, in the short-term that foreign remittance is statistically significant with a negative relationship to GDP. Besides, the result shows that there are no problems of autocorrelation, Hetroskedasticity, and Multicollinearity.
\end{abstract}

Keywords: Foreign remittance, ARDL bound test, ECM, autocorrelation, Hetroskedasticity, Multicollinearity. DOI: $10.7176 / \mathrm{IKM} / 10-7-03$

Publication date:October $31^{\text {st }} 2020$

\section{INTRODUCTION}

\subsection{Overview}

A detailed introduction to this research study is outlined in this chapter. This section describes the study's issue, goal, research hypothesis, significance, and organization.

\subsection{Backgrounds}

Foreign remittance means when the worldwide refuges whose living in foreign countries transferring their money to home countries for their families. Through different sources the remittance is sent to their families such as commercial banks, the hundi market or imported of used goods through relative, associate people as well as through other new network. The main purposes of foreign remittance are to enhance the balance of payments level, reduce poverty, increase domestic investment, decrease unemployment, and improve the living standard of receiver household and low foreign debt in receiving countries. As a result, all these will promote economic growth and development which have a positive effect on the economy of receiving countries.

For many years, Pakistan has attained a substantial quantity of money in the form of remittances through millions of employees who are employed in another country. For low capital intensive like Pakistan, the foreign remittance plays a key role in earning of most foreign exchange reserve. Where foreign remittances are used primarily for consumption and not for investment, then it will fail to create more savings which is necessary for economic growth.

The foremost problems of the study do the foreign remittance and other control variables have a greater effect on the GDP of Pakistan economy and which recommendation can enhance external remittance in Pakistan's economy?

The basic objectives of the current study have tried to examine both the effect and relationship between foreign remittance with other control variables and Pakistan's economic growth. As well as recommending different measures for the improvement of foreign remittance in Pakistan. For this purpose, the research has adopted economic growth as a dependent variable while foreign remittances, domestic saving, investment, export, and import as independent variables. Now, these variables play an important role in the effect of Pakistan's economic growth.

For every country of the world, external remittance remains very useful because it is the causes of significantly positive effect on the economic growth of any country in various form such as to raise domestic saving and investments, per capita income, level of growth, reduce poverty rate, equal distribution of income and also upsurge the foreign exchange reserve. Apart from these, the value of the currency also rises in the international stock market. As such external remittances also play an indispensable role in Pakistan's growth rate based on the above discussion. The significance of the current study has thus also determined the impact and relationship of foreign remittance on Pakistan's economy's growth rate, which will aid future researchers in attempting to bring new economic growth enhancement. 
The remaining paper structures are given: segment 2 represents a review of the literature of the study. Segment 3 contains on the collection of data, methodology, and description of the model. Segment 4 deliberates the experiential outcomes. While segment 5 covers the conclusion and recommendation.

\section{LITERATURE REVIEW}

Burki (1991) studied the social and economic effect of foreign remittance on living standards and the income received from the Middle East has statistically positive.

Muhammad Azam, Muhammad Haseeb, and Shamzaeffa Samsudin (2016) analyzed the foreign remittance effect on poverty alleviation in 39 countries of the world from the period of 1990-2014. The study used the Panel fully modified OLS (FMOLS) which indicates the reduction in the poverty is the cause of an increase in income. Furthermore, the result initiates the impact of foreign remittance on poverty alleviation is positive and statistically significant. Likewise, the external aid and debt on poverty are originating positive effects and both have to represent the positive source of poverty extension.

Janesh Sami (2013) scrutinized the role of growth rate and remittances in the improvement of the banking region in Fiji since 1980-2010. The study used bound tests and estimates the long association ship exists between growth rate, remittances, and advancement of the banking sector. While the ECM shows that economic growth, as well as remittances, causes for the advancement of the banking region.

Rashid Hussain Ghulam Abbas Anjum (2014) called remittance from 1973 to 2011 by the worker to the Pakistan economy. The research employed the Generalized Method of Moments (GMM) for endogenous resistance challenges. The conclusion shows that there is a positive and significant effect on the gross domestic product of Pakistan and the remittances of employees. As well as the effect of trade openness is too significant and positive on GDP.

Mohib Ur Rahman, Khalil Jebran, and Aurang Zeb (2015) reconnoitered the long term affiliation among remittances and Terrorism in Pakistan after 1995 to 2013. The study used different techniques such as unit root test for stationary and Johansen and Juselius Co-integration method for the long-run and short-run correlation among variables. They investigate short and long-run significant link between remittances, terrorism. The result further shows the long and the short-run association ship among remittances and economic growth.

Mobeen Ur Rehman, Faiza Abbasi, and Muhammad Zakaria (2014) investigated the link between remittances of external, FDI, exports, and economic growth of South Asia from 1989-2011. The study discovers the long and short-run connection between these mention variables. Furthermore, the study used FMOLS and DOLS which explore the influence of capital, FDI, remittances, and exports are positive and the labor effect is adverse on GDP.

\subsection{Hypothesis of the Study}

The hypothesis of the study has the evidence from the literature review presented in the above section such as the null hypothesis that has entitled a foreign remittance has no greater effect on the GDP of Pakistan economy. While the alternative hypothesis has specified a foreign remittance has a greater effect on the GDP of Pakistan's economy.

\subsection{Conceptual framework}

The conceptual models of the study are given below;

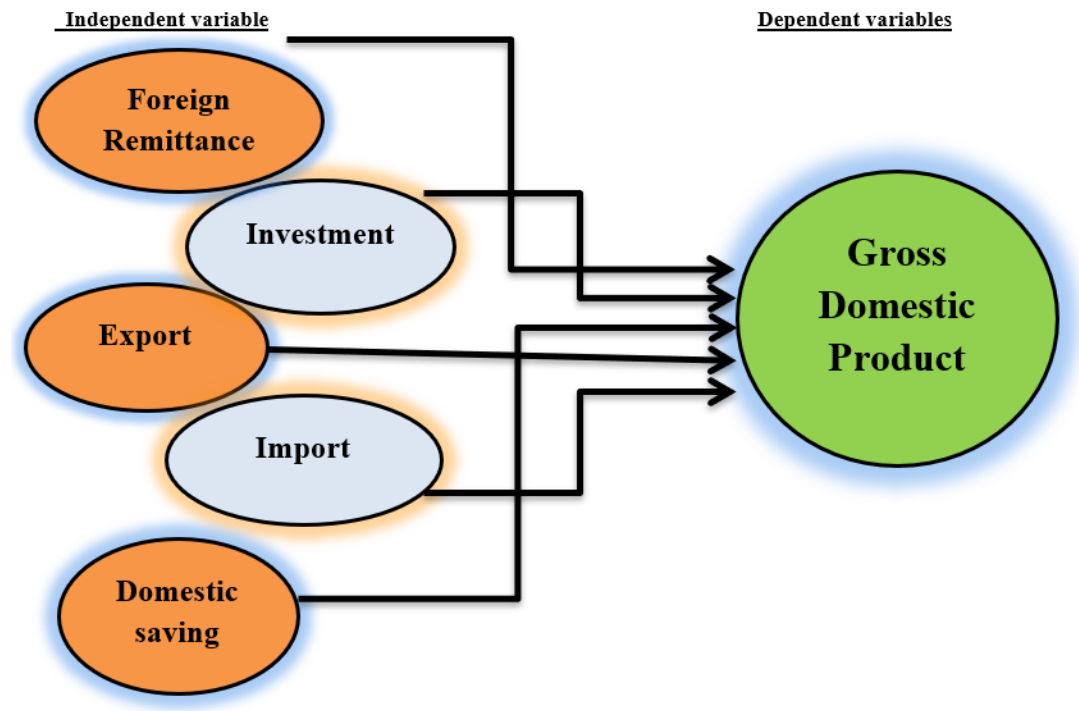




\section{DATA COLLECTION AND METHODOLOGY}

The study concentrated on secondary data, which are from 1974 to 2019 Collected from the world development indicator, an official economic survey of Pakistan, and the papers written. The research used various methods such as the unit root test and the ARDL test to assess the effect and relationship between the variables. For this purpose, the study has taken GDP as the dependent variable and foreign remittances, export, import, domestic saving, and investment as independent variables.

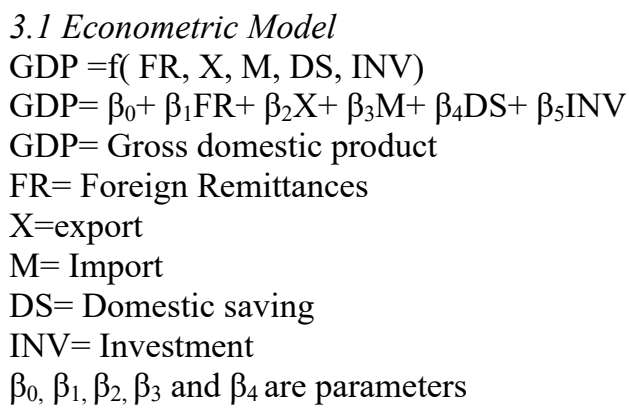

\subsection{Tests for Best Regression}

The overhead model should be good if the following situation will be completed

1. The $\mathrm{R}^{2}$ should be high more than $60 \%$

2. The residual value should be normally distributed.

3. The model should be free from the Hetroscedasticity and Autocorrelation problem.

When all of these circumstances do come true. The model can be observed as a good model of regression for illustrating the influence of foreign remittances on Pakistan's economic development.

\section{DATA ANALYSIS}

4.1 Unit Root Test

Table 4.1.1

ADF test at Level

\begin{tabular}{|llllll|}
\hline Variables & ADF Statistics & $\mathbf{1 \%}$ & $\mathbf{5 \%}$ & $\mathbf{1 0 \%}$ & Order of integration \\
\hline GDP & -5.636824 & -4.180911 & -3.515523 & -3.188259 & Integrated \\
\hline FREM & -1.602283 & -4.180911 & -3.515523 & -3.188259 & Not integrated \\
DS & -3.240731 & -4.180911 & -3.515523 & -3.188259 & Not Integrated \\
INV & -2.273657 & -4.180911 & -3.515523 & -3.188259 & Not integrated \\
EXP & -1.943489 & -4.180911 & -3.515523 & -3.188259 & Not integrated \\
IMP & -1.405784 & -4.180911 & -3.515523 & -3.188259 & Not integrated \\
\hline
\end{tabular}

Source; E-views Statistical Package Version 11 (1974-2019)

Table 4.1.2

ADF test at first difference

\begin{tabular}{|llllll|}
\hline Variables & ADF-statistics & $\mathbf{1 \%}$ & $\mathbf{5 \%}$ & $\mathbf{1 0 \%}$ & Order of integration \\
\hline GDP & -11.57027 & -4.186481 & -3.518090 & -3.189732 & Integrated \\
FREM & 5.505512 & -4.186481 & -3.518090 & -3.189732 & Integrated \\
DS & -7.736797 & -4.186481 & -3.518090 & -3.189732 & Integrated \\
INV & -6.775612 & -4.186481 & -3.518090 & -3.189732 & Integrated \\
EXP & -7.029867 & -4.186481 & -3.518090 & -3.189732 & Integrated \\
IMP & -7.846289 & -4.186481 & -3.518090 & -3.189732 & Integrated \\
\hline
\end{tabular}

Source; E-views Statistical Package Version 11 (1974-2019)

In table 4.1.1 and 4.1.2 the ADF test shows that the entire variable such as FREM, DS, INV, EXP, and IMP are not stationary at a level instead of GDP at 1\%,5\%, and $10 \%$. After this level, we check again unit root test for stationary in the ADF test at the first difference and designates all the variables that are integrated at first level. But based on the current study result, the ARDL model under bound test will be used because some variable is integrated at a level while some at first difference. 


\subsection{VAR Lag Order Selection Criteria}

Endogenous variables: GDP, REM, DS, INV, EXP, IMP

Table 4.2.1

Lag Selection Criteria

\begin{tabular}{|ccccccc|}
\hline Lag & LogL & LR & PPE & AIC & SC & HQ \\
\hline 0 & -2246.040 & NA & $2.06 \mathrm{e}+40$ & 109.8556 & 110.1064 & 109.9469 \\
1 & -2085.794 & 265.7739 & $4.91 \mathrm{e}+37$ & 103.7949 & $105.5502^{*}$ & 104.4341 \\
2 & -2044.339 & $56.62238^{*}$ & $4.23 \mathrm{e}+37$ & 103.5287 & 106.7887 & 104.7158 \\
3 & -1998.301 & 49.40645 & $3.58 \mathrm{e}+37$ & 103.0391 & 107.8036 & 104.7741 \\
4 & -1943.366 & 42.87619 & $2.94 \mathrm{e}+37^{*}$ & $102.1154^{*}$ & 108.3846 & $104.3983^{*}$ \\
\hline
\end{tabular}

Source; E-views Statistical Package Version 11 (1974-2019)

* indicates lag order selected by the criterion

LR: sequential modified LR test statistic (each test at 5\% level)

FPE: Final prediction error

AIC: Akaike information criterion

SC: Schwarz information criterion

HQ: Hannan-Quinn information criterion

According to the table 4.2.1 all these criteria the lag 4 is selected for the sequences of all variables corresponding gross domestic product, foreign remittance, domestic saving, investment, export, and import. Based on lags 4 selections, the ARDL bound test illustrates the result of co-integration.

\subsection{ARDL Model}

4.3.1 The Bound Test

Table 4.3.1

The Bound Test Result

\begin{tabular}{|llcc|}
\hline Model & ARDL & F-statistics & \\
\hline GDP $=$ f( FREM, DS,INV, EXP, IMP) & ARDL $(3,4,0,4,1,3)$ & $7.569910^{* * *}$ & Co-integration \\
FREM = f( GDP, DS, INV, EXP, IMP) & ARDL $(4,3,4,2,3,1)$ & $6.391167^{* * *}$ & Co-integration \\
INV = f( GDP, FREM, DS, EXP,IMP) & ARDL $(2,3,3,3,1,4)$ & $8.607402^{* * *}$ & Co-integration \\
DS = f(GDP, FREM, EXP, INV, IMP) & ARDL $(2,1,3,4,1,4)$ & $10.55380^{* * *}$ & Co-integration \\
EXP = f( GDP, FREM, DS, INV, IMP) & ARDL $(3,3,3,2,1,0$ & $23.85686^{* * *}$ & Co-integration \\
IMP = f( GDP, FREM, DS, INV, EXP) & ARDL $(3,0,3,3,1,2)$ & $7.590693^{* * *}$ & Co-integration \\
\hline Critical Value & Upper bound value I $(1)$ \\
$1 \%$ & \multicolumn{2}{c|}{4.15} \\
$2.5 \%$ & & 3.73 \\
$5 \%$ & 3.06 & 3.38 \\
$10 \%$ & 2.7 & 3.00 \\
\hline
\end{tabular}

Source; E-views Statistical Package Version 11 (1974-2019)

In table 4.3.1 the result of the ARDL bound test demonstrates that there is a long-run relationship between GDP, FREM, INV, DS EXP, and IMP. In each situation, the F-statistics value should be greater than the upper bound value of $1 \%, 5 \%$ and $10 \%$ of the significance level of co-integration among the variables.

4.3.2 Long Run estimate

Table 4.3.2

The Long Run estimate

\begin{tabular}{|lllll|}
\hline \multicolumn{5}{c|}{ Dependent variable (GDP) } \\
\hline Independent variable & Coefficient & Std. Error & T-statistics & Probability \\
\hline FREM & 1.345008 & 0.166550 & 8.075686 & 0.0000 \\
INV & 0.902443 & 0.234156 & 3.854029 & 0.0010 \\
DS & 1.038898 & 0.250453 & 4.148071 & 0.0005 \\
EXP & $2.27 \mathrm{E}-09$ & $2.07 \mathrm{E}-10$ & 10.97587 & 0.0000 \\
IMP & $-1.08 \mathrm{E}-09$ & $1.00 \mathrm{E}-10$ & -10.81270 & 0.0000 \\
Constant & -9.664505 & 4.341142 & -2.226259 & 0.0377 \\
\hline
\end{tabular}

Source; E-views Statistical Package Version 11 (1974-2019)

The table 4.3.2 shows a long-term forecast model for the impact of foreign remittances on the economic development, domestic savings, investment, exports, and imports in Pakistan. The result suggests that foreign remittances, investment, domestic savings, and exports have a direct but statistically significant effect on economic growth in the long-run. It means when any change in these variables leads to a positive influence on the economic 
growth of Pakistan. While the import also statistically significant, but inversely related to the growth rate of the Pakistan economy.

4.3.3 Error correction Mechanism for selected ARDL Model

Table 4.3.3

Error correction Mechanism for selected ARDL Model

\begin{tabular}{|lllll|}
\hline Variables & Coefficient & Std. Error & t-statistics & Probability \\
\hline D(GDP(-1)) & 0.492415 & 0.190791 & 2.580908 & 0.0178 \\
D(GDP(-2)) & 0.316468 & 0.127997 & 2.472469 & 0.0225 \\
D(REM) & -1.213858 & 0.226861 & -5.350670 & 0.0000 \\
D(REM(-1)) & -1.058841 & 0.223154 & -4.744879 & 0.0001 \\
D(REM(-2)) & -0.559632 & 0.252599 & -2.215496 & 0.0385 \\
D(REM(-3)) & 0.884767 & 0.201497 & 4.390975 & 0.0003 \\
D(INV) & -0.714982 & 0.248005 & -2.882936 & 0.0092 \\
D(INV(-1)) & 0.683835 & 0.161196 & 4.242260 & 0.0004 \\
D(INV(-2)) & 0.655489 & 0.206190 & 3.179051 & 0.0047 \\
D(INV(-3)) & 0.568574 & 0.174444 & 3.259342 & 0.0039 \\
D(EXP01) & $-2.93 \mathrm{E}-10$ & $2.26 \mathrm{E}-10$ & -1.297779 & 0.2091 \\
D(IMP) & $2.93 \mathrm{E}-10$ & $1.06 \mathrm{E}-10$ & 2.774438 & 0.0117 \\
D(IMP(-1)) & $3.11 \mathrm{E}-10$ & $6.88 \mathrm{E}-11$ & 4.523629 & 0.0002 \\
D(IMP(-2)) & $2.40 \mathrm{E}-10$ & $6.91 \mathrm{E}-11$ & 3.472886 & 0.0024 \\
CointEq (-1)* & -1.907282 & 0.229799 & -8.299770 & 0.0000 \\
\hline R-squared & 0.880347 & & & \\
Adjusted R-squared & 0.815919 & & & \\
Durbin-Watson stat & 1.865836 & & & \\
\hline
\end{tabular}

Source; E-views Statistical Package Version 11 (1974-2019)

The table 4.3.3 shows that the coefficient of ECM (-1) is -1.90782 which is a negative value and also statistically significant at $5 \%$ of critical value. This will identify that in the short run $1.90 \%$ disequilibrium will be adjusted in long run. The result also shows that foreign remittance is negative, but statistically significantly related to GDP in the short run. Its mean one unit increase in foreign remittances will lead to a 5.350670 unit decrease in GDP of the economy. The value of $\mathrm{R}^{2}$ indicates that $88 \%$ variation in GDP is explained by the variation of FREM, DS, INV, EXP, and IMP show the existence of goodness of fit in the model. The Durbin-Watson value is 1.865836 which is near to 2 . It means the model is free from autocorrelation problem.

\subsection{Breusch-Godfrey Serial Correlation LM test and Hetroskedasticity}

Table; 4.4

End results of Breusch-Godfrey Serial Correlation LM test and Hetroskedasticity

\begin{tabular}{|lll|}
\hline & Prob (F-statistics) & Prob (Obs*R-squared) \\
\hline Breusch-Godfrey Serial Correlation LM Test: & 0.4565 & 0.1808 \\
Hetroskedasticity Breusch-Pagan-Godfrey & 0.6063 & 0.5056 \\
\hline
\end{tabular}

Source; E-views Statistical Package Version 11 (1974-2019)

In table 4.4 the Breusch-Godfrey serial correlation LM test expresses that all the included value of probability is more than 5\%. So as a result, the null hypothesis is accepted that there is no serial autocorrelation in the model. Similarly, the result of Breusch-Pagan-Godfrey for Hetroskedasticity test also indicates that the mention values are greater than 5\% indicating that again acceptance of the null hypothesis and rejection of alternative hypothesis which means no problem of Hetroskedasticity in the model

\subsection{The Normality Test}

Table; 4.5

The Normality Test

\begin{tabular}{|l|l|}
\hline Jarque-Berra value $=2.039504$ & Probability $=0.360684$ \\
Source; E-views Statistical Package Version 11 (1974-2019)
\end{tabular}

The Normality test is illustrated in table 4.6 that Jarque-Berra value is 2.039504 and its probability figure is equal to 0.360684 which greater than 0.05 , it's meant the $\mathrm{H}_{0}$ can accept while rejecting the $\mathrm{H}_{1}$ which shows the residual is normally distributed. 


\subsection{The Ramsey Reset Test}

Table; 4.6

Result of Ramsey Reset Test

\begin{tabular}{|llll|}
\hline & Value & Df & Probability \\
\hline F-statistics & 0.100319 & $(1,23)$ & 0.7543 \\
\hline
\end{tabular}

Source; E-views Statistical Package Version 11 (1974-2019)

In table 4.6 the result of the Ramsey Reset test, the F-statistics value is insignificant at 5\% of the critical value because its $p$-value is greater than $5 \%$. The study indicates that the functional form of all the included variables is correctly specified.

\section{CONCLUSION}

The paper investigates the influence of foreign remittance on the growth rate of the Pakistan economy from 19742019 with data of time-series. After finding, some variables were stationary at a level while some of at the first differences in the model. The ARDL Bound result displays the presence of long-run correlation with Gross Domestic Product and other included variables of the model as well as the ECM result show the short-run relationship among the variables. The results further showed that in long-run foreign remittances, investment, domestic saving, and export is directly but statistically significant effect on economic growth. It means when any change in these variables leads to a positive influence on the economic growth of Pakistan. While the import is also statistically significant, but inversely related to the economic growth of Pakistan. The result also demonstrated that foreign remittance is negative, but statistically significantly related to GDP in the short run.

\section{RECOMMENDATIONS}

Based on the experiential conclusions, the recent study mentioned the following policy implications

1. The government should establish remittances institutions, public authorities, and civil societies to facilitate and reduce the cost of remittance transfers through the financial sector to promote economic development.

2. The Government should promote foreign remittances through raising the level of education in the country as well as skilled.

3. The foreign remittances can be enhanced through the economic barriers.

4. When the Government raises its export income and cut spending to ease the foreign payment burden, at the diplomatic level, it has prepared to draw higher remittances from Pakistani employees overseas

5. If the Government enhance remittances a large source of foreign currency inflows, partly helping to finance foreign spending, import payments, and debt repayments.

6. If the Government made domestic policies that are focused on economic revival to attract higher remittance inflows.

7. If the Government promotes foreign remittances then help to bridge the gap in the balance of payment.

8. Training in the labor force, attitudinal changes, social and psychological improvement also promote foreign remittances.

9. Political changes and diplomatic attitude also promote foreign remittances

10.

6.1 Limitation of the Study

The study has many limitations such as the first limitation is only the area of Pakistan's economy is selected for analysis. The second limitation is the study determined only specific techniques for the analysis of the variables. While the third limitation is only the particular sources are used for data collection in the present study.

\section{REFERENCES}

Acosta, P., Calderón, C., Fajnzylber, P., \& López, H. (2006). Remittances and development in Latin America. World Economy, 29(7), 957-987. https://doi.org/10.1111/j.1467-9701.2006.00831.x

Adamu, P. A. (2013), The impact of foreign aid on economic growth in ECOWAS countries - A simultaneousequation model, WIDER Working Paper No. 2013/143, UNU World Institute for Development Economics Research (UNU-WIDER). http://hdl.handle.net/10419/96314

Aggarwal, R., Demirgüç-Kunt, A., \& Pería, M. S. M. (2011). Do remittances promote financial development?.Journal of development $\quad$ economics, $\quad 96(2), \quad 255-264$. https://doi.org/10.1016/j.jdeveco.2010.10.005

Ahmed, J., Zaman, K., \& Shah, I. A. (2011). An empirical analysis of the remittances-growth nexus in Pakistan using bounds testing approach. Journal of Economics and International Finance, 3(3), 176-186. https://doi.org/10.5897/JEIF.9000008 
Ahmed, R., Vishnu, P., \& Ahmad, N. (2014). Causal relationship between worker remittances and imports in Pakistan. European Journal of Scientific Research, 120(1), 177-188. ISSN: 1450-216X/1450-202X

Ahmad, N., Ahmad, A., \& Hayat, M. F. (2013). Foreign remittances and economic growth in Pakistan: An empirical investigation. https://mpra.ub.uni-muenchen.de/id/eprint/49132

Asghar, A., \& Ashfaq, A. (2004). Remittances not very productively employed. Daily Dawn, Islamabad, Pakistan.

Gupta, S., Pattillo, A.C., Wag, S. (2009) Effect of Remittances on Poverty and Financial Development in SubSaharan Africa, World Development, 37, 104-115. https://doi.org/10.1016/j.worlddev.2008.05.007

Jongwanich, J. (2007). Workers' remittances, economic growth and poverty in developing Asia and the Pacific countries (No. WP/07/01). United Nations Economic and Social Commission for Asia and the Pacific (ESCAP).

Karagoz, K. (2009), Workers remirttances and economic growth: evidence from Turkey, Journal of Yasar University, 4(13), 1890-1908. https://journal.yasar.edu.tr/wpcontent/uploads/2012/05/no13_vol4 01 karagoz.pdf

Kumar, R. R. (2010). Do Remittances matter for Economic Growth of the Philippines? An Investigation using Bounds Test Analysis. An Investigation Using Bounds Test Analysis (February 25, 2010). https://dx.doi.org/10.2139/ssrn.1565903

Muhammad, M., \& Ahmed, J. (2009). A dynamic impact of remittances on economic growth: A case study of Pakistan. German Journal of Economic Studies, 5, 59-74. https://ssrn.com/abstract=2037783

Mbah, S., \& Amassoma, D. (2014). The linkage between foreign aid and economic growth in Nigeria. International Journal of Economic Practices and Theories, 4(6), 1007-1017. http://citeseerx.ist.psu.edu/viewdoc/download?doi=10.1.1.674.5085\&rep=rep1\&type=pdf

Shafqat, M. M., Ahmad, A., \& Bano, S. (2014). Impact of worker remittances on economic growth of Pakistan: Analysis of Pakistan's economy. Journal of Business Research, 6(2), 6-14.

Ugwuegbe, S. U., Okafor, I. G., \& Akarogbe, C. A. (2016). Effect of external borrowing and foreign aid on economic growth in Nigeria. International Journal of Academic Research in Business and Social Sciences, 6(4), 155-175. http://dx.doi.org/10.6007/IJARBSS/v6-i4/2087

Yasmeen, K., Anjum, A., Yasmeen, K., \& Twakal, S. (2011). The impact of workers' remittances on private investment and total consumption in Pakistan. International Journal of Accounting and Financial Reporting, 1(1), 152. https://doi.org/10.5296/ijafr.v1i1.949 